\title{
Response Assessment of Trainees Regarding Physical Arrangement of Training Course
}

\author{
Navjot Kaur, Parminder Singh*, Rajesh Kasrija and S.S. Sodhi \\ Department of Veterinary and Animal Husbandry Extension Education, \\ Guru Angad Dev Veterinary and Animal Sciences University (GADVASU), Ludhiana, India \\ *Corresponding author
}

\section{Keywords}

Dairy, GADVASU,

Piggery, Poultry,

Training, Trainee

Response

Article Info

Accepted:

12 November 2018

Available Online:

10 December 2018

\section{A B S T R A C T}

The present study was conducted by personally interviewing the trainees who have attended pig $(n=69)$, dairy $(n=51)$ and poultry farming $(n=40)$ training course at Guru Angad Dev Veterinary and Animal Sciences University Ludhiana. The satisfaction level of trainees about physical arrangement for training courses was determined on three point continuum i.e. non- satisfied, partially satisfied and satisfied. For Pig farming training course, majority of the trainees with age more than 40 years and with different education level were satisfied with comfortable seating. Majority of the trainees who had sometimes and regularly visited extension specialist were satisfied with comfort seating of the trainees during poultry training course. The satisfaction level of different categories of trainees varies for different physical arrangement facilities. For poultry farmers, there is significance difference $(\mathrm{P}<0.05)$ in satisfaction level for comfortable seating with respect to extension contacts. There is significant difference $(\mathrm{P}<0.01)$ in satisfaction level of dairy farmers for ventilation in the lecture room with respect to age of trainees. Also, for pig farmers there is significant difference $(\mathrm{P}<0.05)$ in satisfaction level for transport facilities with respect to mass media exposure. It indicates that physical arrangements such as comfortable seating, ventilation in lecture room, boarding and lodging arrangements and transport facilities should be appropriate according to categories of trainees for effective execution of training programme.

\section{Introduction}

Training of the farmers through formally arranged courses can be considered to be an intensive teaching activity which should be carefully planned and properly implemented with a view to educate the trainees systematically and thoroughly about a predetermined subject matter. Guru Angad Dev Veterinary and Animal Sciences University (GADVASU), Ludhiana regularly organizes trainings for creating awareness, educating and motivating the farmers, farm women and rural youth to adopt livestock entrepreneurship viz. dairy farming, poultry farming and pig farming. The most of the trainees coming for training were young, educated, belonged to joint families and are married (Navjot Kaur et al., 2018). But, the major problems in training were lack of adequate infrastructure facilities (Vijaipal, 2000). The inadequate physical facilities lead to the difficulty in understanding 
course content (Singh and Roy (1990)). Also, the trainees differ from each other with respect to age, education, mass media exposure and extension contacts. So, present study was planned to assess the response of different categories of trainees regarding physical arrangement of training courses.

\section{Material and Methods}

The present study was conducted on farmers, who have attended the training courses for pig/ dairy and poultry farming at Guru Angad Dev Veterinary and Animal Sciences University Ludhiana. The data were collected by personally interviewing the trainees who have attended pig $(n=69)$, dairy $(n=51)$ and poultry farming $(n=40)$ training course. The satisfaction level of different categories of trainees about physical arrangement for training courses (such as comfortable seating, ventilation in lecture room, arrangement for conducting practicals, boarding and lodging arrangements, transport facilities etc.) was determined on three point continuum i.e. nonsatisfied (NS) partially satisfied (PS) and satisfied (S). The data was analyzed with the help of statistical software Statistical Package for the Social Sciences (SPSS) Version 17.

\section{Results and Discussion}

\section{Comfortable seating}

It is clear from Table 1 that $84.37 \%$ of the trainees with age more than 40 years were satisfied with comfort seating during pig farming training course. Also, the Majority of the trainees with different age group were satisfied with the comfort seating during poultry training course. Majority of the trainees with different education level were satisfied with the comfort seating during the piggery training course. However $57.14 \%$ trainees with education level of senior secondary were satisfied with the comfort seating during the dairy training course. 95.23
$\%$ trainees who were matriculates were also satisfied with the comfort seating during the poultry training course.

$16.66 \%$ trainees who were regularly exposed to mass media were not satisfied with the comfort seating during pig farming training course, but majority of the trainees who were never, sometimes and regularly exposed to mass media were satisfied with the comfort seating during dairy and poultry training course. $90.47 \%$ trainees who had never, sometimes and regularly visited extension specialist were satisfied with comfort seating of the trainees during pig farming training course. Majority of the trainees who had sometimes and regularly visited extension specialist were satisfied with comfort seating of the trainees during poultry training course.

However, Cheema (1982), Kaur (1992), Sodhi (1992) and Ingle and Kudu (1995) reported that majority of the trainees were not satisfied with the physical facilities like boarding and lodging, seating arrangements, library and canteen facilities provided to them during the training course.

Chi-square $\left(\chi^{2}\right)$ test indicate that there is significant difference at 5\% level of significance in satisfaction level of poultry farmers for comfortable seating with respect to extension contacts.

\section{Ventilation in the lecture room}

A perusal of Table 2 indicates that $87.05 \%$ trainees with age group of 25-40 and more than 40 years respectively were satisfied with the ventilation arrangement during pig farming training course. In dairy training course, $59.25 \%$ trainees with age group of less than 25 years were partially satisfied with ventilation arrangement. Majority of the trainees with different age group were satisfied with the ventilation arrangement during poultry training course. 
$88.23 \%$ trainees with education level of matric were satisfied with the ventilation facilities in pig farming training course. However, $48.14 \%$ trainees with education level of senior secondary were partially satisfied with the ventilation facilities in dairy training course. In poultry training course, majority of the trainees with different education level were satisfied with the ventilation facilities.

$88.09 \%$ trainees who were never exposed to mass media were satisfied with the ventilation facilities in the lecture room during pig farming training course. However $48.48 \%$ who were sometimes exposed to mass media were satisfied with the ventilation facilities in the lecture room during dairy training course. In poultry training course majority of the trainees who were sometimes and regularly exposed to mass media were satisfied with the ventilation facilities.

$89.28 \%$ trainees who had sometimes visited extension specialist were satisfied with the ventilation of lecture room during pig farming training courses. However 52.17 and $96.88 \%$ of the dairy and poultry trainees respectively who had sometimes visited extension specialist were satisfied with the ventilation of lecture room. Singh (2013) also revealed that very high percentages of the respondents were satisfied with ventilation and lighting arrangement.

Chi-square $\left(\chi^{2}\right)$ test indicate that there is significant difference at $1 \%$ level of significance in satisfaction level of dairy farmers for ventilation in the lecture room with respect to age of trainees.

\section{Boarding and lodging arrangement}

Table 3 indicates that $87.50 \%$ trainees with age group of 25-40 years were satisfied with the boarding and lodging arrangement during pig farming training course. However, 48.14 $\%$ trainees with age group of less than 25 years were partially satisfied with the boarding and lodging arrangements during dairy training course. These findings are in line with earlier studies by Kaur (1992), Ingle and Kudu (1995) and Sharma (2002).

$80.64 \%$ trainees with education level of matric were satisfied with the boarding and lodging arrangement during pig farming training course. However, $40.74 \%$ trainees with education level of senior secondary were not satisfied with the boarding and lodging arrangement in dairy training course. $66.66 \%$ trainees with education level of graduation were also satisfied with the boarding and lodging arrangement during poultry training course Similar findings were reported by Singh (2014).

$83.33 \%$ trainees who were never exposed to mass media were satisfied with the boarding and lodging arrangement during pig farming training course. However, majority of trainees who were sometimes exposed to mass media were partially satisfied with the boarding and lodging arrangement during dairy training course. In poultry training course, $53.33 \%$ trainees who were never exposed to mass media were satisfied with the boarding and lodging arrangement.

$89.28 \%$ trainees who had sometimes visited extension specialist were satisfied with the boarding and lodging arrangement during pig farming training course. However, $45.45 \%$ trainee who had never visited extension specialist were partially satisfied with the boarding and lodging arrangement during dairy training course. In poultry training course $46.87 \%$ trainees who sometimes visited extension specialist were satisfied with boarding and lodging arrangement but 35.29 $\%$ trainees were not satisfied. 
Table.1 Satisfaction level of trainees w.r.t comfortable seating

\begin{tabular}{|c|c|c|c|c|c|c|c|c|c|c|}
\hline \multirow[t]{2}{*}{ Parameter } & \multirow[t]{2}{*}{ Criterion } & \multicolumn{3}{|c|}{ Pig farming $(n=69)$} & \multicolumn{3}{|c|}{ Dairy farming $(\mathrm{n}=51)$} & \multicolumn{3}{|c|}{ Poultry farming $(n=40)$} \\
\hline & & NS & PS & $\mathbf{S}$ & NS & PS & $\mathbf{S}$ & NS & PS & $\mathbf{S}$ \\
\hline \multirow{4}{*}{$\begin{array}{l}\text { Age } \\
\text { (years) }\end{array}$} & $<25$ & $0(0.00)$ & $3(14.28$ & $18(85.71)$ & $1(3.70)$ & 11(40.74) & $15(55.55)$ & $1(5.88)$ & $0(0.00)$ & $16(94.11)$ \\
\hline & $25-40$ & $0(0.00)$ & $0(0.00)$ & $16(100.00)$ & $2(15.38)$ & $3(23.07)$ & $8(61.53)$ & $0(0.00)$ & $0(0.00)$ & $21(100.00)$ \\
\hline & $>40$ & $2(6.25)$ & $3(9.37)$ & $27(84.37)$ & $3(27.27)$ & $2(18.18)$ & $6(54.54)$ & $0(0.00)$ & $0(0.00)$ & $2(100.00)$ \\
\hline & Chi-square & \multicolumn{3}{|l|}{4.8} & \multicolumn{3}{|l|}{5.6} & \multicolumn{3}{|l|}{1.41} \\
\hline \multirow[t]{5}{*}{ Education } & Matric & $1(3.22)$ & $4(12.9)$ & $26(83.87)$ & $2(50)$ & $1(25)$ & $1(25)$ & $0(0.00)$ & $0(0.00)$ & $8(100)$ \\
\hline & $\begin{array}{l}\text { Senior } \\
\text { Secondary }\end{array}$ & $0(0.00)$ & $0(0.00)$ & 17(100.00) & $2(7.14)$ & $10(37.03)$ & $16(57.14)$ & $1(4.76)$ & $0(0.00)$ & $20(95.23)$ \\
\hline & Graduation & 1(7.69) & $0(0.00)$ & $12(92.30)$ & $1(7.14)$ & $5(35.71)$ & $8(57.14)$ & $0(0.00)$ & $0(0.00)$ & $9(100.00)$ \\
\hline & $\begin{array}{l}\text { Post- } \\
\text { graduation }\end{array}$ & $0(0.00)$ & $2(25.00)$ & $6(75.00)$ & $1(20.00)$ & $0(0.00)$ & $4(80.00)$ & $0(0.00)$ & $0(0.00)$ & $2(100.00)$ \\
\hline & Chi-square & \multicolumn{3}{|l|}{7.97} & \multicolumn{3}{|l|}{7.23} & \multicolumn{3}{|l|}{0.92} \\
\hline \multirow{4}{*}{$\begin{array}{l}\text { Mass } \\
\text { Media } \\
\text { Exposure }\end{array}$} & Never & $0(0.00)$ & $3(7.14)$ & $39(92.85)$ & $0(0.00)$ & $0(0.00)$ & $2(100)$ & $0(0.00)$ & $0(0.00)$ & $15(100)$ \\
\hline & Sometimes & 1(4.76) & 2(9.52) & $18(85.71)$ & $4(12.12)$ & $12(36.36)$ & $17(51.51)$ & 1(6.66) & $0(0.00)$ & 14(93.33) \\
\hline & Regularly & 1(16.66) & $1(16.66)$ & $4(66.66)$ & $2(12.50)$ & $4(25.00)$ & $10(62.50)$ & 00 & $2(20.00)$ & $8(80.00)$ \\
\hline & Chi-square & \multicolumn{3}{|l|}{6.40} & \multicolumn{3}{|l|}{2.25} & \multicolumn{3}{|l|}{1.58} \\
\hline \multirow{4}{*}{$\begin{array}{l}\text { Extension } \\
\text { Contacts }\end{array}$} & Never & 1(4.76) & $1(4.76)$ & 19(90.47) & $2(18.18)$ & $4(36.36)$ & $5(45.45)$ & $1(33.33)$ & $1(33.33)$ & $1(33.33)$ \\
\hline & Sometimes & 1(3.57) & $2(7.14)$ & $25(89.28)$ & $2(8.69)$ & $6(26.08)$ & $15(65.21)$ & $0(0.00)$ & $0(0.00)$ & $32(100.00)$ \\
\hline & Regularly & $0(0.00)$ & $3(15.00)$ & $17(85.00)$ & $2(11.76)$ & $6(35.29)$ & $9(52.94)$ & $1(20.00)$ & $0(0.00)$ & $4(80.00)$ \\
\hline & Chi square & \multicolumn{3}{|l|}{2.28} & \multicolumn{3}{|l|}{1.53} & \multicolumn{3}{|l|}{$6.78 *$} \\
\hline
\end{tabular}

Figure in parenthesis indicate percentage (*): significant at $5 \%$ level 
Table.2 Satisfaction level of trainees w.r.t ventilation in the lecture room

\begin{tabular}{|c|c|c|c|c|c|c|c|c|c|c|}
\hline \multirow[t]{2}{*}{ Parameter } & \multirow[t]{2}{*}{ Criterion } & \multicolumn{3}{|c|}{ Pig farming $(n=69)$} & \multicolumn{3}{|c|}{ Dairy farming $(\mathrm{n}=51)$} & \multicolumn{3}{|c|}{ Poultry farming $(n=40)$} \\
\hline & & NS & PS & $\mathbf{S}$ & NS & PS & $\mathbf{S}$ & NS & PS & $\mathbf{S}$ \\
\hline \multirow{4}{*}{$\begin{array}{l}\text { Age } \\
\text { (years) }\end{array}$} & $<25$ & $1(4.76)$ & $4(19.04)$ & $16(76.19)$ & 1(3.70) & $16(59.25)$ & $10(37.03)$ & $0(0.00)$ & $0(0.00)$ & $17(100.00)$ \\
\hline & $25-40$ & $0(0.00)$ & $2(12.50)$ & $14(87.50)$ & $3(23.07)$ & $3(23.07)$ & $7(53.84)$ & $0(0.00)$ & $1(4.76)$ & $20(95.23)$ \\
\hline & $>40$ & $1(3.12)$ & $3(9.37)$ & $28(87.50)$ & $5(45.45)$ & $0(0.00)$ & $6(54.54)$ & $0(0.00)$ & $0(0.00)$ & $2(100.00)$ \\
\hline & Chi-square & \multicolumn{3}{|l|}{1.86} & \multicolumn{3}{|c|}{$17.15^{* *}$} & \multicolumn{3}{|c|}{0.92} \\
\hline \multirow[t]{5}{*}{ Education } & Matric & $1(3.22)$ & $4(12.90)$ & $26(83.87)$ & $2(40.00)$ & $2(40.00)$ & $1(20.00)$ & $0(0.00)$ & $0(0.00)$ & $8(100.00)$ \\
\hline & $\begin{array}{l}\text { Senior } \\
\text { Secondary }\end{array}$ & $0(0.00)$ & $2(11.76)$ & $15(88.23)$ & $2(7.40)$ & $13(48.14)$ & $12(44.44)$ & $0(0.00)$ & $0(0.00)$ & $21(100.00)$ \\
\hline & Graduation & $1(7.69)$ & $2(15.38)$ & $10(76.92)$ & $4(28.57)$ & $4(28.57)$ & $6(42.85)$ & $0(0.00)$ & $1(11.11)$ & $8(88.88)$ \\
\hline & Post-graduation & $0(0.00)$ & $1(12.50)$ & $7(87.50)$ & $1(20.00)$ & $0(0.00)$ & $4(80.00)$ & $0(0.00)$ & $0(0.00)$ & $2(100.00)$ \\
\hline & Chi-square & \multicolumn{3}{|l|}{1.97} & \multicolumn{3}{|l|}{9.07} & \multicolumn{3}{|l|}{3.31} \\
\hline \multirow{4}{*}{$\begin{array}{l}\text { Mass } \\
\text { Media } \\
\text { Exposure }\end{array}$} & Never & $0(0.00)$ & $5(11.9)$ & $37(88.09)$ & $0(0.00)$ & $1(50.00)$ & $1(50.00)$ & $0(0.00)$ & $1(6.66)$ & $14(93.33)$ \\
\hline & Sometimes & $2(9.52)$ & $3(14.28)$ & $16(76.19)$ & $6(18.18)$ & $11(33.33)$ & $16(48.48)$ & $0(0.00)$ & $0(0.00)$ & $15(100.00)$ \\
\hline & Regularly & $0(0.00)$ & $1(16.66)$ & $5(83.33)$ & $3(18.75)$ & $7(43.75)$ & $6(37.50)$ & $0(0.00)$ & $2(20.00)$ & $8(80.00)$ \\
\hline & Chi-square & \multicolumn{3}{|l|}{4.94} & \multicolumn{3}{|l|}{1.07} & \multicolumn{3}{|l|}{1.58} \\
\hline \multirow{4}{*}{$\begin{array}{l}\text { Extension } \\
\text { Contacts }\end{array}$} & Never & $0(0.00)$ & $4(19.04)$ & $17(80.95)$ & $2(18.18)$ & $5(45.45)$ & $4(36.36)$ & $0(0.00)$ & $1(33.33)$ & $2(66.66)$ \\
\hline & Sometimes & $1(3.57)$ & $2(7.14)$ & $25(89.28)$ & $4(17.39)$ & $7(30.43)$ & $12(52.17)$ & $0(0.00)$ & 1(3.12) & $31(96.87)$ \\
\hline & Regularly & $1(5.00)$ & $3(15.00)$ & $16(80.00)$ & $3(17.64)$ & $7(41.17)$ & $7(41.17)$ & $0(0.00)$ & $0(0.00)$ & $5(100.00)$ \\
\hline & Chi square & \multicolumn{3}{|l|}{2.5} & \multicolumn{3}{|l|}{1.06} & \multicolumn{3}{|l|}{0.19} \\
\hline
\end{tabular}

Figure in parenthesis indicate percentage $(* *)$ : significant at $1 \%$ level 
Table.3 Satisfaction level of trainees w.r.t boarding and Lodging arrangement

\begin{tabular}{|c|c|c|c|c|c|c|c|c|c|c|}
\hline \multirow[t]{2}{*}{ Parameter } & \multirow[t]{2}{*}{ Criterion } & \multicolumn{3}{|c|}{ Pig farming $(n=69)$} & \multicolumn{3}{|c|}{ Dairy farming $(\mathrm{n}=51)$} & \multicolumn{3}{|c|}{ Poultry farming $(n=40)$} \\
\hline & & NS & PS & $\mathbf{S}$ & NS & PS & $\mathbf{S}$ & NS & PS & $\mathbf{S}$ \\
\hline \multirow{4}{*}{$\begin{array}{l}\text { Age } \\
\text { (years) }\end{array}$} & $<25$ & $1(4.76)$ & $6(28.57)$ & $14(66.66)$ & $8(29.62)$ & $13(48.14)$ & $6(22.22)$ & $3(17.64)$ & $5(29.41)$ & $9(52.94)$ \\
\hline & $25-40$ & $1(6.25)$ & $1(6.25)$ & $14(87.5)$ & $3(23.07)$ & $6(46.15)$ & $4(30.76)$ & $4(19.04)$ & $6(28.57)$ & $11(52.38)$ \\
\hline & $>40$ & $1(3.12)$ & $4(12.5)$ & $27(84.37)$ & $3(27.27)$ & $5(45.45)$ & $3(27.27)$ & 00 & $1(50)$ & $1(50)$ \\
\hline & Chi-square & \multicolumn{3}{|l|}{4.19} & \multicolumn{3}{|l|}{3.05} & \multicolumn{3}{|l|}{1.47} \\
\hline \multirow[t]{5}{*}{ Education } & Matric & 1(3.22) & $5(16.12)$ & $25(80.64)$ & $0(0.00)$ & $4(80)$ & $1(20)$ & $3(37.5)$ & $2(25)$ & $3(37.5)$ \\
\hline & $\begin{array}{l}\text { Senior } \\
\text { Secondary }\end{array}$ & $1(5.88)$ & $3(17.64)$ & $13(76.47)$ & $11(40.74)$ & $9(33.33)$ & $7(25.92)$ & $5(23.8)$ & $6(28.57)$ & $10(47.61)$ \\
\hline & Graduation & 1(7.69) & 1(7.69) & $11(84.61)$ & $5(35.71)$ & $6(42.85)$ & $3(21.42)$ & $0(0.00)$ & $3(33.33)$ & $6(66.66)$ \\
\hline & $\begin{array}{l}\text { Post- } \\
\text { graduation }\end{array}$ & $0(0.00)$ & $2(25)$ & $6(75)$ & $1(20)$ & 00 & $4(80)$ & $1(50)$ & $0(0.00)$ & $1(50)$ \\
\hline & Chi-square & \multicolumn{3}{|l|}{1.95} & \multicolumn{3}{|l|}{11.86} & \multicolumn{3}{|l|}{5.72} \\
\hline \multirow{4}{*}{$\begin{array}{l}\text { Mass } \\
\text { Media } \\
\text { Exposure }\end{array}$} & Never & $1(2.38)$ & $6(14.28)$ & $35(83.33)$ & $0(0.00)$ & $2(100.00)$ & $0(0.00)$ & $4(26.66)$ & $3(20.00)$ & $8(53.33)$ \\
\hline & Sometimes & $2(10.00)$ & $3(15.00)$ & $15(75.00)$ & $12(36.36)$ & 13(39.39) & $8(24.24)$ & $3(20.00)$ & $6(40.00)$ & $6(40.00)$ \\
\hline & Regularly & $0(0.00)$ & $2(28.57)$ & $5(71.42)$ & $5(31.25)$ & $4(25.00)$ & $7(43.75)$ & $2(20.00)$ & $2(20.00)$ & $6(60.00)$ \\
\hline & Chi-square & \multicolumn{3}{|l|}{3.41} & \multicolumn{3}{|l|}{5.58} & \multicolumn{3}{|l|}{1.54} \\
\hline \multirow{4}{*}{$\begin{array}{l}\text { Extension } \\
\text { Contacts }\end{array}$} & Never & $2(9.52)$ & $4(19.04)$ & $15(71.42)$ & $3(27.27)$ & $5(45.45)$ & $3(27.27)$ & $1(33.33)$ & $1(33.33)$ & $1(33.33)$ \\
\hline & Sometimes & $1(3.57)$ & $2(7.14)$ & $25(89.28)$ & $8(34.78)$ & $9(39.13)$ & $6(26.08)$ & $8(25)$ & $9(28.12)$ & $15(46.87)$ \\
\hline & Regularly & $0(0.00)$ & $5(25.00)$ & $15(75.00)$ & $6(35.90)$ & $5(29.41)$ & $6(35.29)$ & $1(20.00)$ & $2(40.00)$ & $2(40.00)$ \\
\hline & Chi square & \multicolumn{3}{|l|}{5.28} & \multicolumn{3}{|l|}{0.96} & \multicolumn{3}{|l|}{1.44} \\
\hline
\end{tabular}

Figure in parenthesis indicate percentage 
Table.4 Satisfaction level of trainees w.r.t Transport facilities

\begin{tabular}{|c|c|c|c|c|c|c|c|c|c|c|}
\hline \multirow[t]{2}{*}{ Parameter } & \multirow[t]{2}{*}{ Criterion } & \multicolumn{3}{|c|}{ Pig farming $(n=69)$} & \multicolumn{3}{|c|}{ Dairy farming $(\mathrm{n}=51)$} & \multicolumn{3}{|c|}{ Poultry farming $(n=40)$} \\
\hline & & NS & PS & $\mathbf{S}$ & NS & PS & $\mathbf{S}$ & NS & PS & $\mathbf{S}$ \\
\hline \multirow{4}{*}{$\begin{array}{l}\text { Age } \\
\text { (years) }\end{array}$} & $<25$ & $1(4.76)$ & $3(14.28)$ & $17(80.95)$ & $15(55.55)$ & $9(33.33)$ & $3(11.11)$ & $4(23.52)$ & $2(11.76)$ & 11(64.70) \\
\hline & $25-40$ & $1(6.25)$ & $1(6.25)$ & $14(87.50)$ & $7(53.84)$ & $2(15.38)$ & $4(30.76)$ & $4(19.04)$ & $4(19.04)$ & 13(61.90) \\
\hline & $>40$ & $4(12.50)$ & 1(3.12) & $27(84.37)$ & $6(54.54)$ & $3(27.27)$ & $2(18.18)$ & $0(0.00)$ & $1(50.00)$ & $1(50.00)$ \\
\hline & Chi-square & \multicolumn{3}{|l|}{3.27} & \multicolumn{3}{|l|}{9.13} & \multicolumn{3}{|l|}{3.34} \\
\hline \multirow[t]{5}{*}{ Education } & Matric & $4(12.90)$ & $2(6.45)$ & $25(80.64)$ & $2(40.00)$ & $1(20.00)$ & $2(40.00)$ & $\mathbf{1}(12.50)$ & $1(12.05)$ & $6(75.00)$ \\
\hline & $\begin{array}{l}\text { Senior } \\
\text { Secondary }\end{array}$ & $0(0.00)$ & $2(11.76)$ & $15(88.23)$ & $9(33.33)$ & $10(37.03)$ & $8(29.62)$ & $4(19.04)$ & $1(4.76)$ & $16(76.19)$ \\
\hline & Graduation & $2(15.38)$ & $0(0.00)$ & $11(84.61)$ & $8(57.14)$ & $4(28.57)$ & $2(14.28)$ & $3(33.33)$ & $2(22.22)$ & $4(44.44)$ \\
\hline & $\begin{array}{l}\text { Post- } \\
\text { graduation }\end{array}$ & $0(0.00)$ & $1(12.50)$ & $7(87.50)$ & $2(40.00)$ & $0(0.00)$ & $3(60.00)$ & $0(0.00)$ & $1(50.00)$ & $1(50.00)$ \\
\hline & Chi-square & \multicolumn{3}{|l|}{5.32} & \multicolumn{3}{|l|}{6.30} & \multicolumn{3}{|l|}{5.86} \\
\hline \multirow{4}{*}{$\begin{array}{l}\text { Mass } \\
\text { Media } \\
\text { Exposure }\end{array}$} & Never & $0(0.00)$ & $3(7.14)$ & $39(92.85)$ & $2(100.00)$ & $0(0.00)$ & $0(0.00)$ & $2(13.33)$ & $3(20.00)$ & $10(66.66)$ \\
\hline & Sometimes & $4(19.04)$ & $2(9.52)$ & $15(71.42)$ & $14(42.42)$ & $9(27.27)$ & $10(30.3)$ & $4(26.66)$ & $1(6.66)$ & $10(66.66)$ \\
\hline & Regularly & $2(33.33)$ & $0(0.00)$ & $4(66.66)$ & $5(31.25)$ & $6(37.5)$ & $5(31.25)$ & $2(20.00)$ & $1(10.00)$ & $7(70.00)$ \\
\hline & Chi-square & \multicolumn{3}{|l|}{$12.02 *$} & \multicolumn{3}{|l|}{3.69} & \multicolumn{3}{|l|}{1.74} \\
\hline \multirow{4}{*}{$\begin{array}{l}\text { Extension } \\
\text { Contacts }\end{array}$} & Never & $2(9.52)$ & $1(4.76)$ & $18(85.71)$ & $5(45.45)$ & $3(27.27)$ & $3(27.27)$ & $1(33.33)$ & $1(33.33)$ & $1(33.33)$ \\
\hline & Sometimes & $2(7.14)$ & $2(7.14)$ & $24(85.71)$ & $9(39.13)$ & $6(26.08)$ & $8(34.78)$ & $8(25.00)$ & $4(12.50)$ & $20(62.50)$ \\
\hline & Regularly & $2(10.00)$ & $2(10.00)$ & $16(80.00)$ & $4(23.52)$ & $9(52.94)$ & $4(23.52)$ & $0(0.00)$ & $1(20.00)$ & $4(80.00)$ \\
\hline & Chi square & \multicolumn{3}{|l|}{0.58} & \multicolumn{3}{|l|}{0.82} & \multicolumn{3}{|l|}{2.2} \\
\hline
\end{tabular}

Figure in parenthesis indicate percentage

$(*)$ : significant at $5 \%$ level 


\section{Transport facilities}

Table 4 indicates that $84.37 \%$ trainees with age group of more than 40 years were satisfied with the transport facilities in pig farming training course. However, $53.84 \%$ trainees with age group of 25-40 were not satisfied the transport facilities in dairy training course. These findings are in line with Singh (2014). In poultry training course $61.90 \%$ trainees with age group of 25-40 years were satisfied with the transport facilities. $88.23 \%$ trainees with education level of senior secondary were satisfied with the transport facilities provided during the pig farming training course. However in dairy training course, 40.00 and $60.00 \%$ trainees with education level of matric and postgraduate respectively were satisfied with transport facilities, but $57.10 \%$ of the graduates were not satisfied with the transport facilities during dairy training course. 92.85 $\%$ trainees who were never exposed to mass media were satisfied with the transport facilities during pig farming training course. However, majority of the trainees who were never exposed to mass media were not satisfied with the transport facilities during dairy training course. In poultry training course $66.66 \%$ trainees who were sometimes exposed to mass media were satisfied with the transport facilities. These findings are in line with Singh (2014).

$85.71 \%$ trainees who had sometimes visited extension specialist were satisfied with the transport facilities during pig farming training courses. However $52.94 \%$ who had regularly visited extension specialist were partially satisfied with the transport facilities during dairy training course. In poultry training course, $62.05 \%$ trainees who had sometimes visited extension specialist were satisfied with the transport facilities. Chi-square $\left(\chi^{2}\right)$ test indicate that there is significant difference at $5 \%$ level of significance in satisfaction level of pig farmers for transport facilities with respect to mass media exposure.

The present findings suggests that satisfaction level of different categories of trainees for Pig, Dairy and Poultry farming training course are different. Chi-square $\left(\chi^{2}\right)$ test indicated that there is significant difference $(\mathrm{P}<0.05)$ in satisfaction level of poultry farmers for comfortable seating with respect to extension contacts. There is significant difference $(\mathrm{P}<0.01)$ in satisfaction level of dairy farmers for ventilation in the lecture room with respect to age of trainees. Also, there is significant difference $(\mathrm{P}<0.05)$ in satisfaction level of pig farmers for transport facilities with respect to mass media exposure. The different trainees' categories in different training courses should be taken in to consideration while making physical arrangements for training courses.

\section{References}

Cheema, J. S. 1982. Training needs and gave in knowledge of the trainees of three month practical education in agriculture for the young farmers of Punjab. M.Sc. Thesis, Punjab Agricultural University, Ludhiana, India.

Ingle, P. O. and Kudu, N. R. 1995. Evaluation of KVK programmes. Agriculture Extension Review 7: 3-8.

Kaur, S. P. 1992. Differential contribution of some correlates of trained young farmers influencing their potential effectiveness. Ph.D. Dissertations, Punjab Agricultural University, Ludhiana, India.

Navjot Kaur, Parminder Singh, Rajesh Kasrija and Verma, H.K. 2018. Assessing trainee's profile for better execution of livestock training course. Int. J. Curr. Microbiol. App. Sci. 7(11): 561-566. doi: https://doi.org/10.20546/ijcmas. 2018.711.067. 
Sharma, R. P. 2002. Evaluation of training programmes of Krishi Vigyan Kendra. Journal of Extension Education 13: 3309-13.

Singh, S. and Roy, N. K. 1990. The process of conducting fortnightly training programmes under $\mathrm{T} \& \mathrm{~V}$ system. Indian Journal of Extension Education 26: 121-25.

Singh, K. 2013. Reactions of the trainees about three months training course of practical education in agriculture for young farmers organized by PAU, Ludhiana. M.Sc. Thesis, Punjab Agricultural University, Ludhiana, India.

Singh, K. 2014. Reactions of the Trainees about Dairy Entrepreneurship training course organized by Punjab dairy development board at Bija, Ludhiana. M.V.Sc Thesis, GADVASU, Ludhiana, India.

Sodhi, A. 1992. A comparative study of the organisational set up per training to the transfer of technology and extension training programmes at Agricultural Universities in India. Ph.D. Dissertation, Punjab Agricultural University, Ludhiana, India.

Vijaipal, G. S. 2000. Staff development, status, problems, challenges and opportunities for professional development of non academic staff of the Indian universities. University News Journal of Higher Education 38: 1-4.

\section{How to cite this article:}

Navjot Kaur, Parminder Singh, Rajesh Kasrija and Sodhi, S.S. 2018. Response Assessment of Trainees Regarding Physical Arrangement of Training Course. Int.J.Curr.Microbiol.App.Sci. 7(12): 1626-1634. doi: https://doi.org/10.20546/ijcmas.2018.712.190 